\title{
THE CORRECTION OF MEAN CELL VOLUME AND MEAN CELL HAEMOGLOBIN CONCENTRATION
}

\author{
BY \\ RALPH E. BERNSTEIN \\ From the Department of Physiology, the University of the Witwatersrand, South Africa
}

(RECEIVED FOR PUBLICATION DECEMBER 24, 1954)

The determination of red cell constants is important in the diagnosis of certain blood disorders and in following the response to therapy. The accuracy of the mean cell volume (M.C.V.) and the mean cell haemoglobin concentration (M.C.H.C.) is dependent on the precision and reproducibility of the individual estimations. It is widely accepted (Wintrobe, 1951 ; Whitby and Britton, 1953) that the haematocrit determination $(<1 \%$ error) is more accurate than the haemoglobin estimation (2-3\% error) and considerably more accurate than the red cell count $(7-10 \%$ minimum error). In this respect, we may confirm the reproducibility of the haematocrit determination since duplicates, set up in $3 \mathrm{~mm}$. Wintrobe tubes and spun simultaneously in the same centrifuge, agree within less than 0.5 divisions, read to the nearest tenth of a division by microscopic magnification against an eyepiece scale.

However, while techniques for haemoglobin estimation and red cell counting are standardized, those for the haematocrit determination are less so. Haematological and clinical pathological texts, among others those of Dacie (1950), Wintrobe (1951), and Whitby and Britton (1953), quote a variety of speeds and times of centrifugation, usually 20-30 minutes at 2,000-3,000 r.p.m. Nevertheless, the actual completeness of packing depends on the size and shape of the red cells and the centrifugal force applied and its duration. Oxygenated red cells are smaller than cells containing a high concentration of reduced haemoglobin, while only heparin and the ammonium-potassium oxalate mixture as anticoagulants do not alter red cell volume (Adams and Mosher, 1951 ; Bernstein, 1953).

\section{Experimental}

Fresh aerated heparinized blood samples from male medical students were divided and spun in capped $3 \mathrm{~mm}$. Wintrobe tubes in a standard laboratory centrifuge with a $15 \mathrm{~cm}$. radial head. The tachometer speeds were checked stroboscopical!y. The packed cell column decreased rapidly in tubes spun for 45 min. between 2,000 and 3,000 r.p.m. (relative centrifugal force to bottom of tube, 670-1,510 g), with a lesser decrease between 3,000 and 4,500 r.p.m. (1,510$3,400 \mathrm{~g})$. Representative results are detailed in Table I, together with the mean relative haematocrit values for 22 samples, taking the haematocrit reading at 4,500 r.p.m. as 100 .

TABLE I

HAEMATOCRIT OF NORMAL BLOOD SAMPLES SPUN AT VARIOUS CENTRIFUGAL FORCES

\begin{tabular}{|c|c|c|c|c|}
\hline $\begin{array}{l}\text { Speed of } \\
\text { Centrifu- } \\
\text { gation } \\
\text { (r.p.m.) }\end{array}$ & $\begin{array}{c}\text { Relative } \\
\text { Centrifugal } \\
\text { Force* } \\
\text { (g.) }\end{array}$ & $\begin{array}{l}\text { Haematocrit } \\
\text { Sample } 1 \\
(\%)\end{array}$ & $\begin{array}{c}\text { Haematocrit } \\
\text { Sample } 2 \\
(\%)\end{array}$ & $\begin{array}{c}\text { Mean } \\
\text { Relative } \\
\text { Haematocrit } \dagger\end{array}$ \\
\hline $\begin{array}{l}1,500 \\
2,000 \\
2,500 \\
3,000 \\
3,500 \\
4,000 \\
4,500\end{array}$ & $\begin{array}{r}378 \\
670 \\
1,050 \\
1,510 \\
2,055 \\
2,684 \\
3,400\end{array}$ & $\begin{array}{l}54.8 \\
51.6 \\
48.8 \\
47.4 \\
45.6 \\
45.0 \\
45.0\end{array}$ & $\begin{array}{l}57.6 \\
55.0 \\
52.5 \\
49.8 \\
48.2 \\
47.6 \\
47.4\end{array}$ & $\begin{array}{l}122 \\
116 \\
109 \\
105 \\
102 \\
101 \\
100\end{array}$ \\
\hline
\end{tabular}

* Calculated for radial distance $(15 \mathrm{~cm}$.) to bottom of Wintrobe tube.

$\dagger$ Haematocrit at 4,500 r.p.m. taken as 100 .

The duration of spinning at any centrifugal speed also influences the packed cell column; there is a moderate decrease between 20 and 30 minutes, with little further change between 45 and 90 minutes (Fig. 1).

The degree of red cell packing was ascertained by direct estimation of the trapped intercellular plasma, using inulin or T1824 as plasma-marking agents. For example, $1 / 10$ volume of $0.5 \%$ Evans blue (T1824) dye was mixed with the heparinized specimens and placed in $3 \mathrm{~mm}$. Wintrobe tubes in duplicate for centrifugation at different speeds and times. Supernatant plasma $(0.1 \mathrm{ml}$.) was serially diluted $1 / 250,1 / 500,1 / 1,000$ in $0.9 \% \mathrm{NaCl}$ to provide individual standards for reading each test sample (Evelyn photometer, $620 \mathrm{~m} \mu, 6 \mathrm{ml}$. aperture, $2 \mathrm{~cm}$. cells).

The dyed plasma remaining in the haematocrit was discarded by adding saline with careful successive aspiration, followed by removal of the buffy coat and superficial red cell layer. The red cell level was noted for calculation of cell volume $\left(\mathrm{V}_{\mathrm{RB}^{-}}\right)$-for example, $3.1416 \times(0.15)^{2} \times 4.3=0.304 \mathrm{ml}$. The haematocrits 
were weighed with mercury to the 4 and $5 \mathrm{~cm}$. marks to check the volume.

The packed cells were carefully removed to a $10 \mathrm{ml}$. volumetric flask, the haematocrit and aspirating pipette being repeatedly rinsed with saline, and the density of the centrifuged supernate read. The trapped intercellular plasma in $\mathrm{ml}$. is calculated:

$$
0.1 \times \frac{\mathrm{T}}{\mathrm{S}} \times \frac{10-\mathrm{V}_{\mathrm{RBC}}}{\mathrm{V}}
$$

where $\mathrm{T}$ and $\mathrm{S}=$ density of test and standard respectively

$\mathrm{V} \quad=$ volume of diluted standard, i.e. 25. 50 , or 100

and is expressed as a percentage of the volume of red cells $\left(V_{R B C}\right)$.

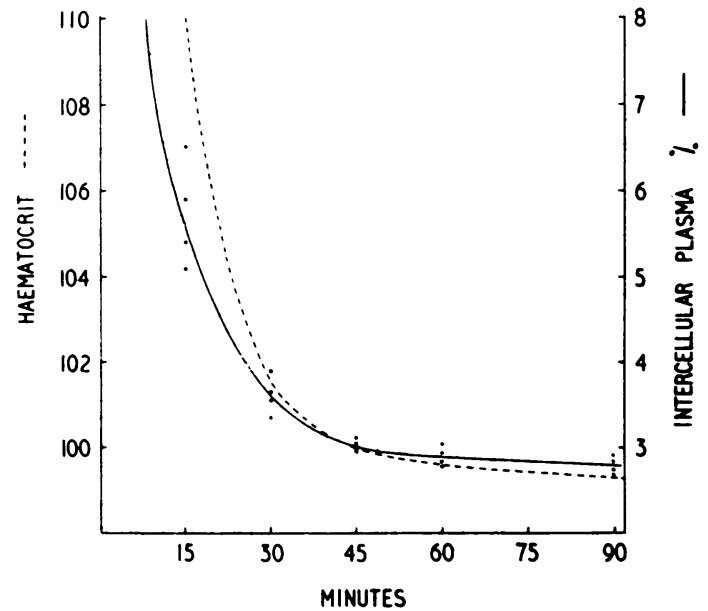

FIG. 1.-Percentage intercellular plasma trapped and relative haematocrit values for four normal blood samples, centrifuged for different times at 3,500 r.p.m., radial head $15 \mathrm{~cm}$. $(\times 2,050 \mathrm{~g})$.

The plasma volume trapped in the red cell mass was $4-12 \%$ at 2,000 to 3,000 r.p.m. spun for 45 to 60 minutes with a 10 to $20^{\circ}$ \% coefficient of variation, in contrast to the $1.8-3 \%$ trapping at the higher speeds with a $5 \%$ coefficient of variation. Thus the amount of plasma trapped intercellularly, and, more particularly, the degree of variation in packing, was of a very variable order with the slower rates of spinning. Recent reviews and investigations (Gregersen, 1951: Leeson and Reeve, 1951 ; Chaplin and Mollison, 1952) indicate that a force of at least $2,000 \mathrm{~g}$ is required to obtain reproducible packing of red cells. Our results confirm such a conclusion, and centrifugation at 3.500 r.p.m. with a $15 \mathrm{~cm}$. head $(\times 2,050 \mathrm{~g})$ for 45 minutes has been adopted as routine procedure.
For bloods with widely differing packed cell columns spun under standard conditions the observed trapped $\overrightarrow{\bar{F}}$ intercellular plasma decreases with reduction in the haematocrit reading. This ensues from the increase in centrifugal force (calculated to the mid-point of the $\frac{\bar{c}}{\bar{\omega}}$. cell column) being applied to decreased packed cell columns (Table II).

TABLE II

INFLUENCE OF VARIATION IN HAEMATOCRIT AND $\overrightarrow{0}$ RESULTING CENTRIFUGAL FORCE ON TRAPPED INTERCELLULAR PLASMA

\begin{tabular}{|c|c|c|c|}
\hline \multirow{4}{*}{$\begin{array}{l}\text { Observed haematocrit }(\%) \\
\text { Mid-radius of centrifugation } \\
\text { (cm.) . } \\
\text { Relative centrifugal force (g) } \ldots \\
\text { Observed trapped intercellular } \\
\text { plasma }(\%) \quad \ldots \\
\text { Corrected haematocrit }(\%) \quad \ldots\end{array}$} & 65 & 50 & 35 \\
\hline & 11.75 & $12 \cdot 50$ & 13.25 \\
\hline & 1,610 & 1,710 & 1,815 \\
\hline & $\begin{array}{r}3 \cdot 5 \\
62.7\end{array}$ & $\begin{array}{r}28 \\
48.6\end{array}$ & $\begin{array}{r}2 \cdot 2 \\
34 \cdot 2\end{array}$ \\
\hline
\end{tabular}

\section{Comment}

The mean haematocrit for the 22 samples was 50.1, range 45.2-53.8, S.D. 2.1 (altitude $5,740 \mathrm{ft}$. and the corrected haematocrit 48.5. The corrected? M.C.V.would be some $4 \%$ lower and the M.C.H.C $\overrightarrow{6}$ some $3 \%$ higher for these normal specimens. Theer correction would be greater for polycythaemio blood and less in anaemias. Provided that thes haematocrit is centrifuged for at least 45 minutes at 3,500 r.p.m. in a $15 \mathrm{~cm}$. radial head, the errow in neglecting the trapped intercellular plasma in reading the packed cell column is relatively con stant, so that reports from different laboratories are comparable. Under other conditions of centri fugation, the errors are variable and considerable

Apart from the necessity for standardizing the conditions of the haematocrit determination in the calculation of haematological indices, the correc tion of the packed cell volume for the amount of. trapped intercellular plasma is of particular im@ portance in estimating $(a)$ the total blood volume after cell or plasma volume has been determinedo and $(b)$ the distribution of solutes between blood cells and plasma (Bernstein, 1952).

\section{REFERENCES}

Adams, A. R., and Mosher, W. A. (1951). Blood, 6, 661. Bernstein, R. E. (1952). S. Afr. J. med. Sci., 17, 101. (1953). Ibid., 18, 99.

Chaplin, H., Jr., and Mollison, P. L. (1952). Blood, 7, 1227. Dacie, J. V. (1950). Practical Haematology, Churchill, London. Gregersen, M. I. (1951). Ann. Rev. Physiol., 13, 397.

Leeson, D., and Reeve, E. B. (1951). J. Physiol., Lond., 115, 129. Whitby, L. E. H., and Britton, C. J. C. (1953). Disorders of the Bloode

7th ed. Churchill, London. Febiger, Philadelphia. 